\title{
KÖRÖS ÁKOS
}

koros.akos@icloud.com

PhD-hallgató

(Szent István Egyetem Enyedi György Regionális Tudományok Doktori Iskola)

\section{Kiszombor veszteségei az elsố világháborúban az anyakönyvi vizsgálatok alapján}

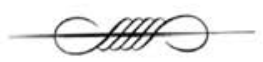

\begin{abstract}
In this paper, I examined how a medium-sized Hungarian village affected by the First World War. I had two questions about the damage. How many casualties did the settlement have during the war? How did the demographic impact of the losses look like in the village?

Kiszombor was a Hungarian, Catholic village in the middle of the Great Plain in Hungary between two cities: Szeged and Makó. 4000 people had lived there around the beginning of the $20^{\text {th }}$ century, most of them made a living lived from agriculture. The village was the center of the Rónay family's estate.

I counted 101 dead in 1916-1920 in the burial registers. Most of them died in 1917. The most common month was the December because the author of the records could not know the exact date of their death. Therefore they used the $31^{\text {st }}$ of December formula. The deceased distribution by profession or religion is following the rate of the village's population. The soldiers' age were between 18 and 48 years, most of the dead $(9 \%)$ were 31 years old.

The majority of the deceased were married. This issue caused the most crucial problem in the village. $10 \%$ of the men between $20-60$ died in the war; therefore the number of the $0-6$ years old population decreased by $35 \%$. The population growth stopped in the $1910 \mathrm{~s}$, as the community reached the carrying capacity of the land and stagnation started in the late 1900's. Although after the war, the growth of the population increased significantly.

Naturally, there were slightly more women than men in the village. During the war, this rate increased and reached six percentage points of difference. In 1920 there were 240 more women than men, even though the disparity decreased at the end of the decade.

The regional comparison is quite impressive. Looking at settlements in the 30 kilometer radius of Kiszombor. The average loss was 3\% of the whole population of Hungary, however Kiszombor's result is much higher $(5 \%)$. We can say that one quarter of the population was enlisted and $5 \%$ of the population died in the war from this region.
\end{abstract}




\section{KEYWORDS}

First World War, casualties, historical demography, local history, social history

DOI 10.14232/belv.2018.1.3～https://doi.org/10.14232/belv.2018.1.3

Cikkre való hivatkozás / How to cite this article: Körös, Ákos (2018): Kiszombor veszteségei az első világháborúban az anyakönyvi vizsgálatok alapján. Belvedere Meridionale 30. évf. 1. sz. 35-44. pp.

ISSN 1419-0222 (print) ISSN 2064-5929 (online, pdf)

(Creative Commons) Nevezd meg! - Így add tovább! 4.0 (CC BY-SA 4.0)

(Creative Commons) Attribution-ShareAlike 4.0 International (CC BY-SA 4.0)

www.belvedere-meridionale.hu

\section{BEVEZETÉS}

\section{Kutatási kérdés}

Kiszombor első világháborús veszteségeinek a felmérésével ilyen módon ismereteim szerint még senki sem foglalkozott. Alapvetően történeti demográfiai oldalról igyekeztem megközelíteni a témát, azaz a hősi halottaknak nemcsak az adatai érdekeltek, de szerettem volna az otthonmaradottakat is vizsgálni. Az anyakönyvekhez való hozzáférés korlátozott lehetősége ${ }^{1}$ miatt árnyalnom kellett a kérdést és tanulmányomban már csak az elhunytakra vonatkozó adatokat és a település természetes szaporulatát elemeztem.

A magyarországi első világháborús veszteségek vizsgálata még gyermekcipőben jár. A kétezres évek elején KANYÓ Ferenc (2000) jelentetett meg egy listás összeírást a szegedi hősi halottakról. Ezen kívül csak olyan tanulmányokat találtam, amely bizonyos tulajdonságok szerint csoportosítja az elhunytakat. BESENYEI Vendel (2013) a Jászberényi temetőket vizsgálta meg, míg RAVASZ István (2014) immár a jubileum keretein belül a háború első veszteseivel foglalkozott. Talán KóTAI István (2014) választotta tanulmányában a legérdekesebb csoportosítást: az elesett állatorvosokat vette számba.

Tanulmányom szempontjából leginkább azok a vizsgálatok érdekesek, amelyek településenként tekintették át az első világháborús halottak listáit. Az első ezek között HeGEDŰs Elemér (2016), aki a soproni születésű hősöket vizsgálta. Szintén 2016-os DÁvID Benjámin tanulmánya, amely - azon túl, hogy e mű ihletője volt - bemutatja a mai Gyomaendrőd egyik felének, Endrődnek az első világháborús veszteségeit. Egy egészen friss eredmény pedig BoJTos Gáboré (2017), amely Szolnok világháborús monográfiájában található. Eredményeikhez anyakönyvi forrásokat felhasználtak.

\footnotetext{
A születési anyakönyvek csak 1917-ig elérhetőek.
} 


\section{Kiszombor társadalma a 20. század elején}

Az első világháború kirobbanásának a jól ismert és elengedhetetlen politikai casus belli-n, azaz az 1914. június 28-ai szarajevói gyilkosságon túl az időben messzebbre visszanyúló társadalmi-gazdasági okai is voltak. A 19. századi modernizációs folyamatok mind egy konfliktus felé mutattak. A mezőgazdaságban leginkább a termőtalaj minőségének javítása, valamint a gépesítés és az emberi munkaerő használatának a maximalizálása, az iparban az erőgépek alkalmazása, a mindennapi életben az egyre többféle erőforrások sokszínű felhasználása megteremtette a lehetőséget a hatalmas nemzetállamok kialakítására és annak adminisztrációjának a tökéletesítésére, amihez a század elején kiépített oktatásszervezet hűségesen statisztált. (KIss 2015. 53-55.) Ebbe a modernizációs folyamatba illeszkedik bele a címben szereplő vizsgált település is nagyuradalmi központ révén.

Kiszombor a Dél-Alföldön, a Maros-folyó bal partján, Makó és Szeged között, a 20. század elején Torontál vármegye északi részén helyezkedett el. A 19. században a lakosságszám dinamikus növekedést mutatott. A 4000 főt az 1900-as évek elején lépte át, a háború előestéjén kicsit több, mint száz fővel többen laktak a településen. (KSH 1930.)

A lakosság 78\%-a a mezőgazdaságból élt meg, további 4\%-uk (napszámosok) szorosan kapcsolódtak ahhoz. A szekunder szektorba a lakosság 9\%-a tartozott, míg a tercierbe a lakosság 7\%-a. További $1 \%$ egyéb kereső volt. A teljes lakosság mintegy $43 \%$-a volt kereső. A tercier szektor - és ezen belül is az értelmiség - aránya meglepően magas volt egy falusi környezethez képest. A többség valószínüleg a közigazgatásban helyezkedett el, amely alacsonyabb jövedelemmel kecsegtetett, azonban a nagybirtok vonzereje e tekintetben is megmutatkozik. (MARJANUCZ MAROSVÁRI 2008. 324.)

\section{ELEMZÉS}

\section{Elesettek}

A faluról készült monográfia a plébánia Historia Domus-ára hivatkozva összesen 185 elesett katonát említ, azonban kiemeli, hogy a pontos számadat megállapítása nehézséget okoz. (HALMÁGYI - MAROSVÁRI 2008. 336.) Ezzel szemben az én, a kiszombori állami anyakönyvek adataiból, valamint a hivatalos veszteséglistákból (VERLUSTLISTE 1914-1919) összeállított adatbázisomban összesen 101 bejegyzés szerepel. Igen nagynak tünik a különbség. Sajnos az nem derül ki, hogy a Historia Domus milyen forrásból szerezte az információit, így az ellenőrzést nem lehet elvégezni.

1914 és 1920 között 101 elesett köthető biztosan Kiszomborhoz. A legtöbben a háború első felében estek el: 83 fő (82\%). A legtöbb elesettet 1917-re datálták a források, de hasonlóan magas eredményeket ért el az 1915-ös év is.

Az elesettek egyharmada decemberre van datálva. Feltehetően nem mindannyian decemberben estek el, hanem az adott évben, akiknek az adatát nem tudták pontosan, azt december 31-ére írták be. $10 \%$ feletti értéket ért el még november és megközelíti azt az augusztus és az április. A legkevesebben (2\%) februárban estek el.

Az elesettek beosztását tekintve vegyes eredményeket kaptam. 45 fó esetében nem volt felvezetve semmilyen adat, így ezeket a vizsgálatból kizártam. A beosztással rendelkező elesettek 48\%-a népfölkelő volt. $10 \%$ feletti arányt képviselnek a gyalogosok. $4 \%$ feletti arányt értek el 


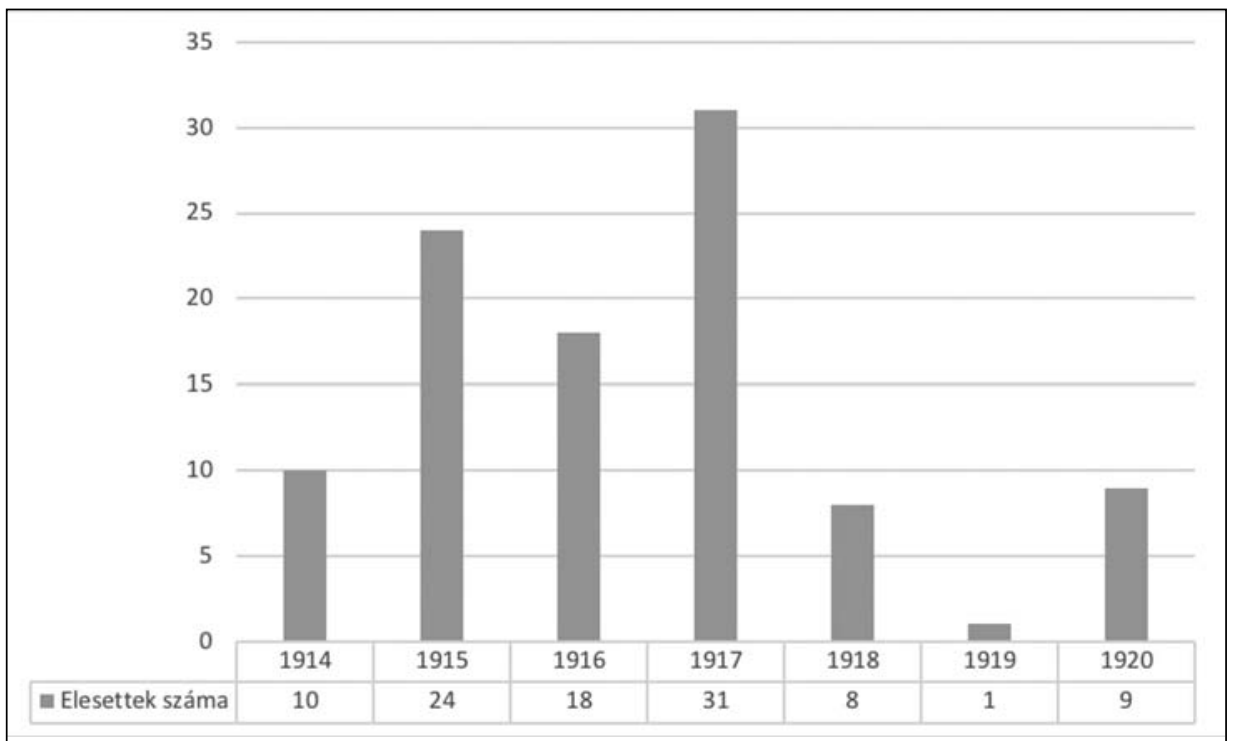

1. ÁBRA A kiszombori első világháborús hősi halottak száma évente 1914-1920 között (Szerkesztette: Kőrös Ákos, 2018)

az őrvezetők, tizedesek, póttartalékosok, honvédek, vadászok. Egy-egy elhalálozott van a további rangokból: szakaszvezető, honvédőrvezető, mozdonyvezető, tüzér, póttartalékos közlegény, alvadász, tartalékos, őrmester, főorvos, főtüzér.

Sokszor nem volt feltüntetve, hogy mely hadtesthez tartozott a zombori elesett. Az 54 esetböl az elesettek 37\%-a a Magyar Királyi 5. Honvéd Gyalogezredhez tartozott. További 17\% a Császári és Királyi 46. gyalogezredhez. Három-három fö tartozott a Császári és Királyi 3. tábori vadászzászlóaljhoz, a 3. honvéd huszárezredhez. Az 5-ös honvédek laktanyája Szegeden a Honvéd téren, míg a 46-osoké a Mars téren volt. (HALMÁGYI - MAROSVÁri 2008. 332.)

Az elhunytak foglalkozásának a felvezetése jellemzően akkor nem került sorra, amikor a bejegyzést a háború után készítették el. ${ }^{2}$ A 70 foglalkozási bejegyzéssel rendelkező elesett túlnyomó többsége (69\%) földműves volt. Ezt követi 6\%-kal a napszámos. A kézművesek, értelmiségiek 1-2 fővel képviseltetik magukat (szolga, kocsis, cipész, mészáros, főorvos, bognár mester, gazdasági cseléd, MÁV fékező, gépészmérnök, szitás, borbély, vendéglős, kazánfúvó, zenész, kerékgyártó, kertészsegéd).

Az elesettek vallási összetétele követi a lakosság vallási összetételét. A 61 vallásra vonatkozó adattal rendelkező elesettek 95\%-a római katolikus volt. Rajtuk kívül két református és egy görög katolikus került be az adatbázisba.

Az elesettek életkora a legtöbb esetben le volt jegyezve vagy ki lehetett számolni. Az átlag elhalálozási életkor 29,8 év volt. A legfiatalabb zombori hősi halott 18, míg a legidősebb 48 éves volt. Az életkoradattal rendelkező elhunytak 9\%-a 31 éves volt. A részletes korosztályi megoszlás a 2. ábrán látható.

\footnotetext{
${ }^{2}$ Az anyakönyvekben egészen 1972-ig találhatóak bejegyzések első világháborús hősi halottakról.
} 


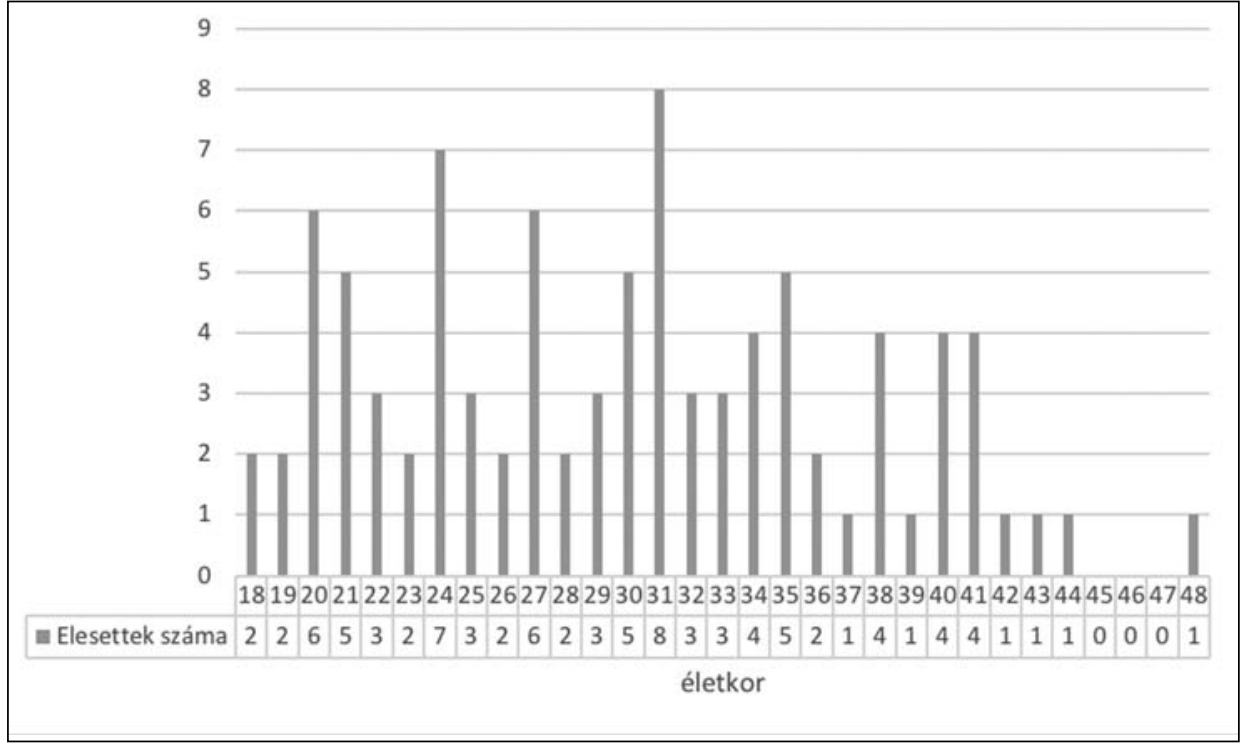

2. ÁBRA A kiszombori első világháborús hösi halottak száma az elhalálozási koruk szerint 1914-1920 között (Szerkesztette: Kőrös Ákos, 2018)

Az elesett katonák családi állapotát tekintve a többségük már volt házas. Pont a felük özvegyasszonyt hagyott maga után hátra, $2 \%$-uk már eleve özvegy, 35\%-uk pedig nőtlen volt. A bejegyzések 13\%-ánál nem lehet megállapítani a családi állapotot. Egy alföldi összehasonlítás érdekében négy korcsoportra osztottam az elhunytakat és ebben a felosztásban vizsgáltam a családi állapotukat. Ezen eredmények az 1. táblázatban találhatóak. Ebből az elemzésből kizártam azon bejegyzéseket, ahol vagy az elhalálozás kora vagy a családi állapot nem volt feltüntetve. Az eredmény összecseng DÁVID (2016) eredményeivel. A legnagyobb korcsoportot a fiatalok alkotják, akik $90 \%$-a nőtlen volt. Ez komoly hatással lehetett a háború utáni település természetes szaporulatára. ${ }^{3}$

\begin{tabular}{|l|c|c|c|c|}
\hline & Házas & Nőtlen & Özvegy & Összes \\
\hline $\mathbf{1 8 - 2 4}$ & 3 & 22 & 0 & $25(32 \%)$ \\
\hline $\mathbf{2 5 - 3 1}$ & 13 & 10 & 1 & $24(30 \%)$ \\
\hline $\mathbf{3 2 - 3 9}$ & 18 & 0 & 0 & $18(23 \%)$ \\
\hline $\mathbf{4 0}$ és felette & 11 & 1 & 0 & $12(15 \%)$ \\
\hline Összesen & $45(57 \%)$ & $33(42 \%)$ & $1(1 \%)$ & 79 \\
\hline
\end{tabular}

1. TÁBLÁZAT A zombori első világháborús hösi halottak száma családi állapotuk és korosztályuk csoportositása szerint 1914-1920 között (Szerkesztette: Kőrös Ákos, 2018)

\footnotetext{
${ }^{3}$ Ennek pontosabb kimutatására ismerni kellene az időszak korfáját és az elhunytaknak a település azonos korú lakosságához viszonyított arányához.
} 


\section{Demográfiai hatások}

A népesség növekedését az első világháborús veszteségek nem gátolták. Amint az a 3. ábrán látható, a lakosság növekedésének az üteme a 19. század végén lassult és ebbe a trendbe illeszkedik bele az első világháborús stagnálás. A háborút követően a lakosságszám korábban nem látott sebességgel növekedett.

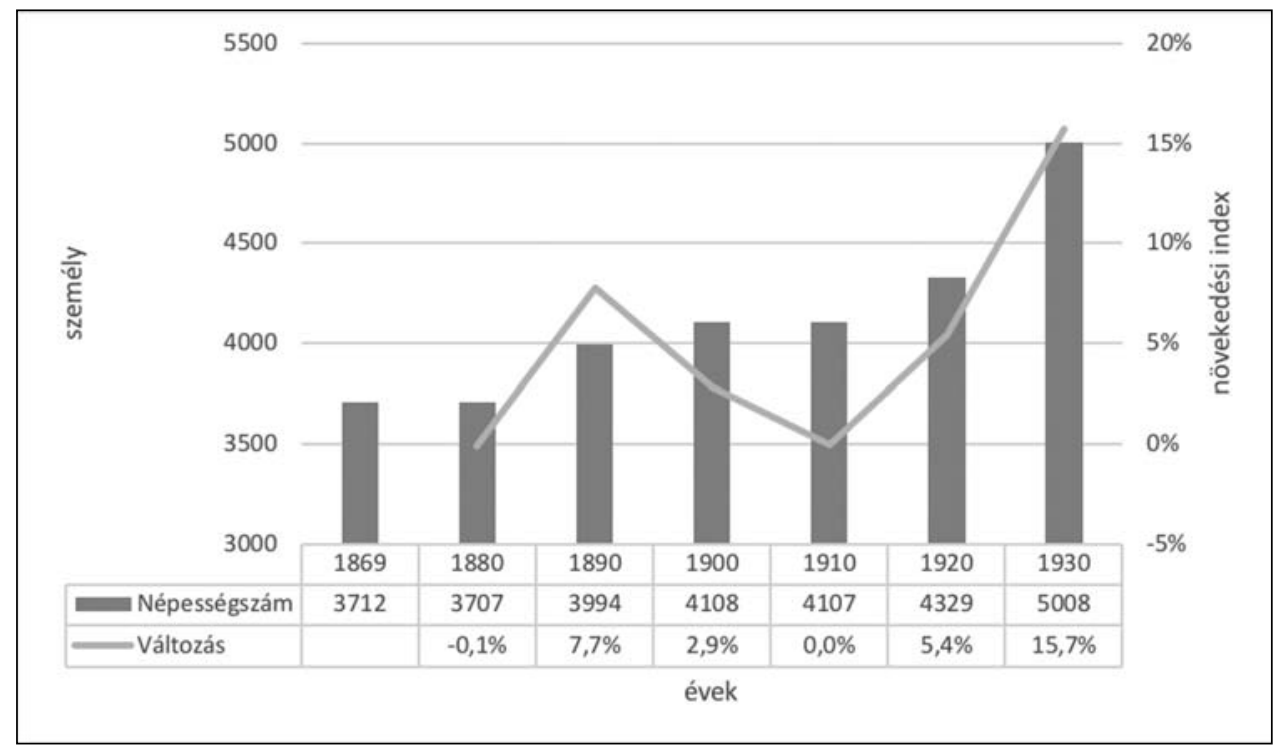

3. ÁBRA Kiszombor lakosságszáma és annak változásai 1869 és 1930 között az elözö évhez viszonyitva (KSH 1930). (Szerkesztette: Kőrös Ákos, 2018)

A korösszetétel szerinti változás vizsgálatának az eredménye egyértelműen mutatja, hogy a háború alatt a 6 évnél fiatalabbak száma jelentősen, 35\%-kal visszaesett 1910 és 1920 között. (KSH, 1920) Ugyanebben az időszakban a 40-59 év közöttiek aránya 69\%-kal megnőtt. Az 1910-es népszámlálás adatai szerint (KSH, 1910) a húsz és hatvan év közöttiek összesen 1995 fö. Ennek 5\%-a, a 20-60 közötti férfiak $10 \%$-a elesett a háborúban. Ennek eredménye, hogy kevesebb gyermek született ${ }^{5}$ a háború alatt és hogy az idősebb korcsoportok aránya megnövekedett. Az 1930-as évekre a 6 év alatti korcsoport adatai utolérik az 1910-es szintet, tehát a háború utáni időszakban a háborús veszteségek korrigálódnak tíz év alatt.

A családi állapotok szerinti megoszlás vizsgálatának eredménye azt mutatja, hogy az 1920-as évekre (KSH, 1920) az özvegyek száma 33\%-kal nőtt, hiszen sokuknak a házastársa odaveszett a háborúban. A házasok 1920-ban 9\%-kal voltak többen, mint 1910-ben és 1930-ban 20\%-kal, mint egy évtizeddel korábban. (KSH 1930) Itt is tapasztalható tehát, hogy a házasodási szokásokat a nagyszámú férfihiány nem zökkentette ki a menetéből, legfeljebb a házasodási intenzitás lendületét vetette vissza kicsit.

\footnotetext{
${ }^{4}$ Az 1910-es korcsoport szerinti adatokat és a szintén 1910-es nemi arányokat használtam.

${ }^{5}$ Tekintve, hogy az elhalálozottakon túl a háborút túlélt többi katona sem tartózkodott Kiszomborban a háború alatt.
} 
A nemek szerinti megoszlás ábrázolása látványos különbséget mutat. A nőtöbbletet az 5\%-os férfihiány sem fordította meg, azonban jelentős arányeltolódásokat okozott. A 4. ábrán a lakosságszámot adtam meg nulla kezdettel, az 5. ábrán azonban a nemek össznépességhez viszonyított arányát. Látható, hogy az 1920-as évekre 240 fős nőtöbblet alakul ki, ami az 1930-as évekre korrigál és visszakerül eredeti pozíciójába. Az 1920-as évekre tehát 6 százalékpontos eltérés alakul ki a két nem között, ami jelentősnek mondható. Az arányokon láthatjuk, hogy a háború okozta emberi erőforrásveszteség még egy évtizeddel később is éreztette hatását a házassági piacon Kiszomborban.

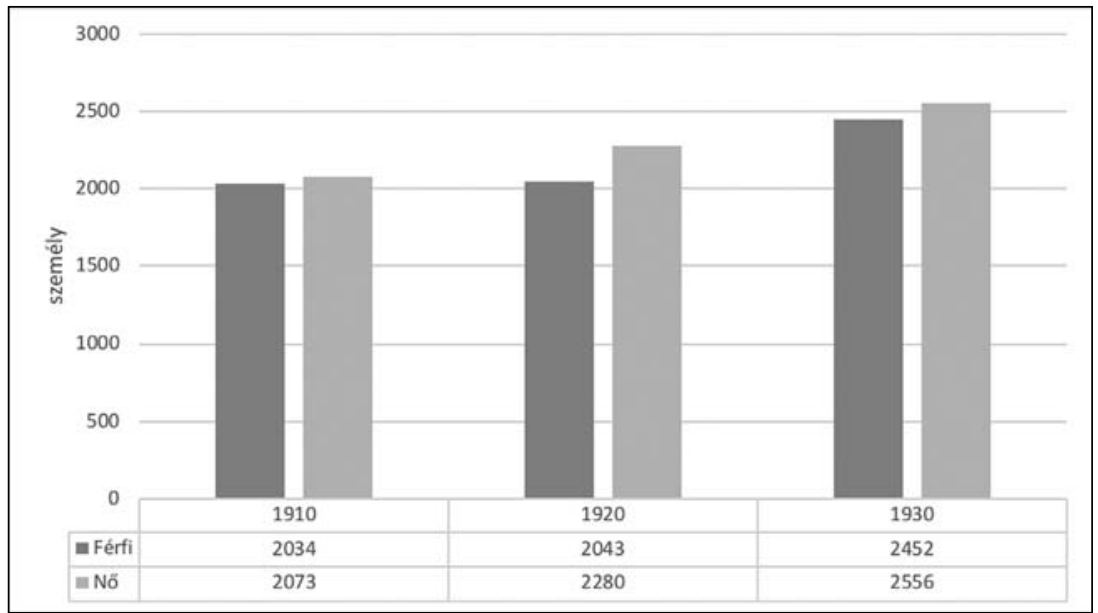

4. ÁBRA Kiszombor lakosságának megoszlása nemek szerint az 1910-es, 1920-as és 1930-as népszámlálás adatai alapján (KSH 1910; KSH 1920; KSH 1930).

(Szerkesztette: Kőrös Ákos, 2018)

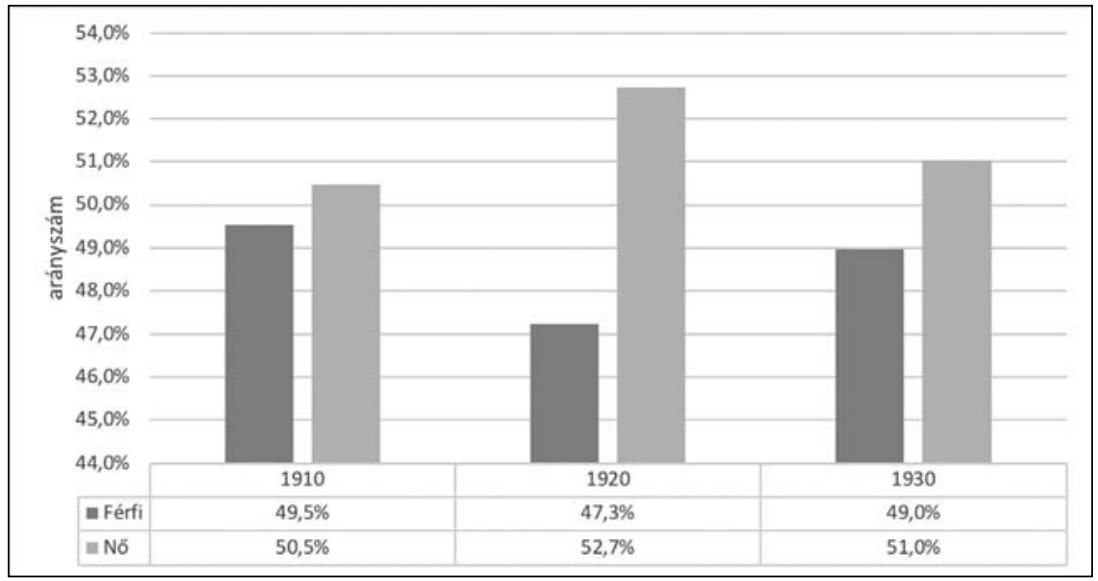

5. ÁBRA Kiszombor lakosságának nemek szerinti megoszlása az 1910-es, 1920-as és az 1930-as népszámlálás adatai alapján (KSH, 1910; KSH, 1920; KSH, 1930).

(Szerkesztette: Kőrös Ákos, 2018) 


\section{Régiós összehasonlítás}

A kiszombori eredmények az országos eredményhez képest magasabbak. A 18 milliós országból (KSH, 1930) több, mint hárommillióan kerültek a frontokra és 530 ezren nem jutottak onnan haza (SzABÓ 2002. 497.). Ez a teljes lakosság 3\%-a.

A 2. táblázatban összesítettem a régió néhány településének fellelhető adatait. Az első oszlopban található lakosságszám az 1910-es népszámlálás adatait mutatja (KSH 1930). Apátfalva URBANCSOK Zsolt munkája alapján látható. Sajnos a mű forrást nem jelölt meg, de a szám egyezik a műemlékre bevésett nevek számával (URBANCSOK 2016. 63.). Szeged esetében három elmélet él, mindhármat feltüntettem. (BLAZOVICH 2007. 139.) Makó adatai a település monográfiájából származnak (SzABÓ 2002. 497.). A többi település Halmágyi Pál emlékműveket összegző gyűjtéséből van, tehát ezesetben nem demográfiai forrásokat feldolgozó műről, hanem a valamilyen módszertan alapján elkészült müemléki veszteséglistákat összegezte. (HALMÁGYi 1998. 10-13.) Mivel a müemléken szereplő adatok és az anyakönyvek által feltárható adatok mennyiségei nem minden esetben egyeznek meg, ezért úgy gondolom, hogy ezek az adatok csak becslésekként használhatóak.

\begin{tabular}{|l|c|c|c|c|c|c|}
\hline \multicolumn{1}{|c|}{ Település } & $\begin{array}{c}\text { Lakosság- } \\
\text { szám (1910) }\end{array}$ & $\begin{array}{c}\text { Sorozott } \\
\text { (fö) }\end{array}$ & $\begin{array}{c}\text { Sorozott } \\
\mathbf{( \% )}\end{array}$ & Elhunyt & $\begin{array}{c}\text { Elhunyt - } \\
\text { sorozott (\%) }\end{array}$ & $\begin{array}{c}\text { Elhunyt - } \\
\text { lakosság (\%) }\end{array}$ \\
\hline Apátfalva & 5642 & 1400 & $25 \%$ & 173 & $12 \%$ & $3 \%$ \\
\hline Kiszombor & 4107 & n. a. & - & 185 & - & $5 \%$ \\
\hline Szeged - Banner & 118328 & n. a. & - & 9500 & - & $8 \%$ \\
\hline Szeged - Kováts & 118328 & n. a. & - & 6630 & - & $6 \%$ \\
\hline Szeged - Kanyó & 118328 & n. a. & - & 3554 & - & $3 \%$ \\
\hline Makó & 34918 & 8500 & $24 \%$ & 1300 & $15 \%$ & $4 \%$ \\
\hline Ambrózfalva & 1042 & n. a. & - & 53 & - & $5 \%$ \\
\hline Csanádalberti & 1370 & n. a. & - & 80 & - & $6 \%$ \\
\hline Csanádpalota & 6096 & n. a. & - & 480 & - & $8 \%$ \\
\hline Nagymajláth - Nagyér & 1011 & n. a. & - & 39 & - & $4 \%$ \\
\hline Pitvaros & 2936 & n. a. & - & 133 & - & $5 \%$ \\
\hline Földeák & 5126 & n. a. & - & 245 & - & $5 \%$ \\
\hline Maroslele & 2172 & n. a. & - & 78 & - & $4 \%$ \\
\hline Királyhegyes & 1078 & n. a. & - & 73 & - & $7 \%$ \\
\hline Magyarcsanád & 3105 & n. a. & - & 111 & - & $4 \%$ \\
\hline Klárafalva & 570 & n. a. & - & 16 & - & $3 \%$ \\
\hline Kübekháza & 1817 & n. a. & - & 73 & - & $4 \%$ \\
\hline Átlag & 25057 & & & 1337 & & $5 \%$ \\
\hline
\end{tabular}

2. TÁBLÁZAT Kiszombor és környéki települések I. világháborús veszteségeinek összesitése (Forrás: KSH 1930.; URBANCSOK 2016; Blazovich 2007; Szabó 2002; HalMÁGYi 1998) 
Összesen két helyről van adatunk arra vonatkozóan, hogy mennyien lettek kivonva a település társadalmából. Mindkét esetben a lakosság egynegyede körüli az érték. Ebből én következtetést nem merek levonni, de további kutatások hipotéziseként fel lehet tenni a kérdést, hogy vajon ez általános volt-e az országban.

A települések lakosságának a 3-8\%-a halt hősi halált az első világháborúban. A régiós átlag $5 \%$ volt, ami két százalékponttal magasabb, mint az országos eredmény. Ez számottevő különbség.

\section{ÖSSZEGZÉS}

Sokatmondó és fontos téma a háború demográfiai vizsgálata a társadalomtörténet és az első világháború történetének írásában. Digitális formában elérhetőek a levéltárban, valamint az időszakra vonatkozó népszámlálási adatok a KSH Könyvtár tudásbázisában, ezért a kis falvak, alacsony létszámú települések első világháborús veszteségeinek az elemzése az anyakönyvek alapján könnyen elvégezhető. Garantáltan az örömömre szolgálna, ha a fent felsorolt műveken túl a közeljövőben születnének még alföldi települések veszteségeinek az ilyen jellegü összeírásai, elemzései, hogy egy átfogó képet lehessen kapni a régióról.

\section{FelHasznált irodalom}

Besenyei Vendel (2013): Az I. világháború hősi halottai Jászberény temetőiben. Jászsági Évkönyv 1. sz. 73-88.

Blazovich LÁszló (szerk.) (2007): Szeged rövid története. Szeged.

Bojtos GÁBOR (2017): Szolnok és az első világháború. Hátország, hősök, emlékezet. Szolnok, MNL Jász-Nagykun-Szolnok M. Lvt.

DÁvID BENJÁMIN (2016): Endrőd hősi halottai az első világháborúban. Belvedere Meridionale 28. évf. 4. sz. 94-107.

Halmágyi PÁl (1998): Az I. és II. Világháború hösei, áldozatai és emlékmüvei Makón és környékén. A Makói Múzeum Füzetei, 89.

HALMÁGYi PÁl - MAROSVÁRI ATTILA (2008): Az első világháborútól a második végéig. In Marosvári Attila (szerk.): Kiszombor története I. Kiszombor, Kiszombor Község Önkormányzati Képviselőtestülete. $332-449$.

HeGEDŰS ELEMÉR (2016): Soproni születésű hősi halott tisztek Galíciában. Soproni Szemle 70. évf. 1. sz. 102-115.

KANYÓ FERENC (2000): Ismertté vált újabb szegedi hősi halottak és áldozatok. Tanulmányok Csongrád megye történetéböl 23. évf. 2. sz. 19-101.

KISS GÁBOR FERENC (2015): Erőviszonyok az első világháború előestéjén. In Kiss Gábor Ferenc Vincze Gábor (szerk.): „Kedves bajtársim kössétek be sebem”. A nagy háború emlékezete. Ópusztaszer - Szeged, Ópusztaszeri Nemzeti Történeti Emlékpark - Belvedere Meridionale. 49-73. 
KÓTAI IsTVÁN (2014): Az I. világháború állatorvos hősi halottjai. Magyar állatorvosok lapja 136. évf. 3. sz. 754-762.

KSH 1910.: Központi Statisztikai Hivatal (1910): A Magyar Szent Korona országainak 1910. évi népszámlálása. 1. r. A népesség főbb adatai községek és népesebb puszták, telepek szerint. http://konyvtar.ksh.hu/inc/kb_statisztika/Manda/MSK/MSK_042.pdf (letöltés dátuma: 2018. január 17.)

KSH 1920.: Központi Statisztikai Hivatal (1920): Az 1920. évi népszámlálás. 1. r. A népesség főbb demográfiai adatai községek és népesebb puszták, telepek szerint. http://konyvtar.ksh.hu/inc/ kb_statisztika/Manda/MSK/MSK_069.pdf (letöltés dátuma: 2018. január 17.)

KSH 1930.: Központi Statisztikai Hivatal (1930): Az 1930. évi népszámlálás. 1. r. Demográfiai adatok községek és külterületi lakotthelyek szerint. http://konyvtar.ksh.hu/inc/kb_statisztika/ Manda/MSK/MSK_083.pdf (letöltés dátuma: 2018. január 17.)

MARJANuCz LÁszló - MAROSvÁRI AtTILA (2008): A polgárosodó falu. In Marosvári Attila (szerk.): Kiszombor története I. Kiszombor, Kiszombor Község Önkormányzati Képviselő-testülete, 253-332.

RAVASZ IstVÁN (2014): A nagy háború első halottai. Hadtörténelmi Közlemények 127. évf. 3. Sz. 754-762.

SZABÓ FERENC (szerk.) (2002): Makó története 1849-töl 1920-ig. Makó.

URBANCSOK ZsOLT (2016): „,...mint fatörzsböl gyönge ága...”. Apátfalva története és a csanádi térség a kezdetektől 1956-ig. Apátfalva, Apátfalva Község Önkormányzata.

VERLUSTLISTE (1914-1919): http://anno.onb.ac.at/anno-suche\#searchMode=complex\&text= kiszombor \&dateMode $=$ period $\&$ from $=1 \&$ sort $=$ date + asc $\&$ selectedFilters $=$ title $\% 3$ Avll (letöltés dátuma: 2018. január 04.) 